\title{
Cumulative exposure to inorganic lead and neurobehavioural test performance in adults: an epidemiological review
}

\author{
John M Balbus-Kornfeld, Walter Stewart, Karen I Bolla, Brian S Schwartz
}

\begin{abstract}
Objectives-To evaluate the current evidence that cumulative exposure to inorganic lead is associated with decreased performance in neurobehavioural tests in adults.
\end{abstract}

Methods-21 unique studies were reviewed from 28 published manuscripts. An algorithm was developed to determine the usefulness of each study on the basis of exposure assessment, control of confounding variables, methods of subject selection, test conditions, and data analysis. Highest emphasis was placed on the use of cumulative measures of exposure or absorption.

Results-Only three studies used a measure of cumulative exposure to or absorption of lead, and two others used duration of exposure as a surrogate for cumulative exposure. All other studies used a measure that did not adequately estimate cumulative exposure to lead, most often current blood lead concentration. 20 of the studies controlled for age as a confounding variable, although in several studies the possibility for residual confounding by age remained. 16 studies controlled for intellectual ability before exposure; all of them used educational level for this purpose. Of the five studies that used direct or surrogate measures of cumulative exposure to or absorption of lead, two were thought to be of low usefulness because of inadequate duration of exposure. The three remaining studies found stronger associations of neurobehavioural performance with recent exposure measures than with those of cumulative exposure.

Conclusion-The current scientific literature provides inadequate evidence to conclude whether or not cumulative exposure to or absorption of lead adversely affects performance in neurobehavioural tests in adults. The current evidence is flawed because of inadequate estimation of cumulative exposure to or absorption of lead and inadequate control for age and intellectual ability before exposure.

(Occup Environ Med 1995;52:2-12)

Keywords: lead; neurotoxins; neuropsychological tests

Although the detrimental effect of low to moderate exposure to lead on the central nervous system (CNS) has been generally accepted in children, ${ }^{1}$ such an effect remains controversial in adults. Manifestations of lead intoxication of the CNS in adults have been well described and consist of ataxia, memory loss, and at the highest levels coma and death. Low to moderate exposure has been consistently associated with symptoms of malaise, fatigue, irritability, lethargy, headache, and decreased libido. ${ }^{2-5}$ Such exposure has also been reported to decrease neurobehavioural test scores in the cognitive or motor domains of psychomotor speed, manual dexterity, memory, and learning ability. These quantitative tests are more reproducible than symptom scores and are the only currently available measures of the functional integrity of the CNS.

An important unresolved issue is whether cumulative exposure to lead causes chronic dysfunction of the CNS in adults. Although several methods exist to estimate cumulative exposure to or absorption of lead, recent blood lead concentrations are inadequate in this regard. ${ }^{6}$ Associations found with recent blood lead concentrations may reflect transient and reversible changes because this measure reflects primarily exposure received in the most recent few months, especially in currently exposed workers. We report the results of a rigorous evaluation of the evidence that cumulative exposure to lead is associated with decreased neurobehavioural test performance in adults.

\section{Methods}

MEDline, NIOSHTIC, HSELINE (British emphasis-published by the Health and Safety Executive) and CISDOC (international emphasis-published by the International Occupational Safety and Health Information Centre of the UN Labour Organisation) databases were searched with the keywords lead, neurotoxicity, and neurobehavioural. Also, the references of papers identified from the literature searches were examined to identify other studies. Peer reviewed studies were considered if they included adults exposed to inorganic lead, performed neuropsychological tests, and did not involve mixed exposures to neurotoxins.

Each study was scored for its ability to specifically examine the association between cumulative exposure to lead and neurobehavioural function. The overall score was based on an assessment of the following factors: the method by which neurobehavioural data were 
collected; the definition of exposure; prospective $v$ cross sectional design; use of a nonexposed group, and if a non-exposed group was used its comparability with the exposed group; and the adequacy of methods of control for potential confounding variables. The rationale for selecting and priority given to each factor, as well as the specific criteria used, are described.

\section{EXPOSURE ASSESSMENT}

Studies were evaluated for the extent to which they estimated cumulative exposure to or absorption of lead. Four methods were considered adequate for this purpose. Firstly, cumulative exposure could be calculated as the product of intensity of exposure (estimated from industrial hygiene data) and duration of exposure for each job that involved exposure to lead. Secondly, cumulative lead absorption could be directly measured as lead in bone by $x$ ray fluorescence. Although not an estimate of total lead body burden, chelatable lead (most often estimated as the amount of lead excreted in the urine for six or 24 hours after a $1 \mathrm{~g}$ intravenous dose of ethylenediamine tetraacetate (EDTA)) was also considered to be a third relevant surrogate for cumulative absorption because chelatable lead is thought to reflect the total bioavailable lead pool. ${ }^{7}$ A fourth measure that was thought to provide an accurate estimate of cumulative absorption was the sum of the products of interval blood lead concentrations and the time intervals between samples. Such a measure requires blood lead samples from the entire duration of exposure to be most useful. This is equivalent to the area under the curve of a plot of blood lead concentrations $v$ time for the period of employment in jobs exposed to lead, which in turn has been shown to correlate highly with bone lead as measured by $x$ ray fluorescence. ${ }^{7}$

Studies that used any one of these four methods were considered to be the most useful for this review. Studies that used duration of employment alone as a surrogate for cumulative exposure were considered useful, because duration of exposure is likely to be an adequate estimate of cumulative dose for toxins with long half lives such as inorganic lead. ${ }^{8}$ The use of time weighted averages - for example, of blood lead, zinc protoporphyrin (ZPP), or intensity of exposure-alone was considered less useful, as two subjects with the same time weighted average could differ substantially in duration and therefore cumulative dose. Studies that used recent biological measures-for example, current blood lead, ZPP, urinary aminolevulinic acid (ALAU)-were also thought to be of low usefulness. Growing evidence has shown that the current blood lead concentration, for example, is an inadequate estimate of the total absorbed dose of lead. ${ }^{7910}$

Duration of exposure and its variation among study subjects was also assessed. Although no threshold has been established below which cumulative effects of lead would not be expected, a population comprising people with predominantly short term exposure (less than three years) would be less likely to show a cumulative effect of lead than one with a longer duration of exposure.

CONTROL OF CONFOUNDING VARIABLES In order of priority, the following factors were considered to be the most important potential confounding variables:

\section{Age}

Neurobehavioural performance declines with increasing age. The age at which such decline becomes obvious as well as the extent of the decline, however, vary with both sex and the specific test. ${ }^{1112}$

\section{Intellectual functioning before exposure}

Capability and performance before exposure are highly predictive of test performance after a toxic exposure. ${ }^{13}$ In the absence of data on intellectual functioning before exposure, verbal intelligence measures-for example, the Wechsler adult intelligence scale revised (WAIS-R) vocabulary score-and years of education are often used to control for differences before exposure. Although the number of years of education is easy to measure and is not affected by exposure to neurotoxins, it is a modest predictor of capability before exposure. On the other hand, the WAIS-R vocabulary subscore may correlate well with performance on a range of neurobehavioural tests, but there are few data to support the contention that it is resistant to the effects of neurotoxins. Despite these limitations, however, there are no realistic alternatives to these surrogate measures, and their use is preferable to not considering the issue. Studies were therefore evaluated for adequacy of control for capability before exposure.

\section{Sex}

Neurobehavioural test performance has been associated with sex, but the magnitude of the associations differs for the specific test. ${ }^{1011}$ Studies were assessed for their control for sex differences.

\section{Alcohol}

Acute alcohol intoxication affects neurobehavioural test performance. Studies were therefore evaluated as to whether recent alcohol ingestion was evaluated. It is less clear, however, that a history of chronic alcohol ingestion is a significant confounding variable. ${ }^{14}$ Control for chronic alcohol ingestion was assessed, but was not considered to be of great importance.

\section{Other neurotoxins}

Solvents, carbon disulphide, heavy metals, and other substances have all been shown to affect neurobehavioural performance. Studies were evaluated on adequacy of control for earlier exposure to other neurotoxins in both exposed and non-exposed subjects.

\section{STUDY DESIGN}

Prospective studies offered several advantages 
over cross sectional studies: firstly, they could separate effects of past exposure from recent exposure; secondly, they enabled comparisons of groups both in terms of cross sectional neurobehavioural functioning and changes in function over time. The comparison of function over time would allow direct assessment of functioning before exposure if the subject entered the study at the time of initial employment; alternatively, measurement of change in neurobehavioural function over time, if subjects were old, would allow an estimate of the rate of decline in neurobehavioural function associated with aging.

Subject selection and recruitment methods were considered most useful when they were population based and minimised self selection. Participation and drop out rates were evaluated; at least $50 \%$ participation was thought to be essential.

\section{DATA COLLECTION}

We considered four factors that could contribute to group differences: (a) if computerised tests were not used, blinding of examiners to exposure; (b) uniform test con-

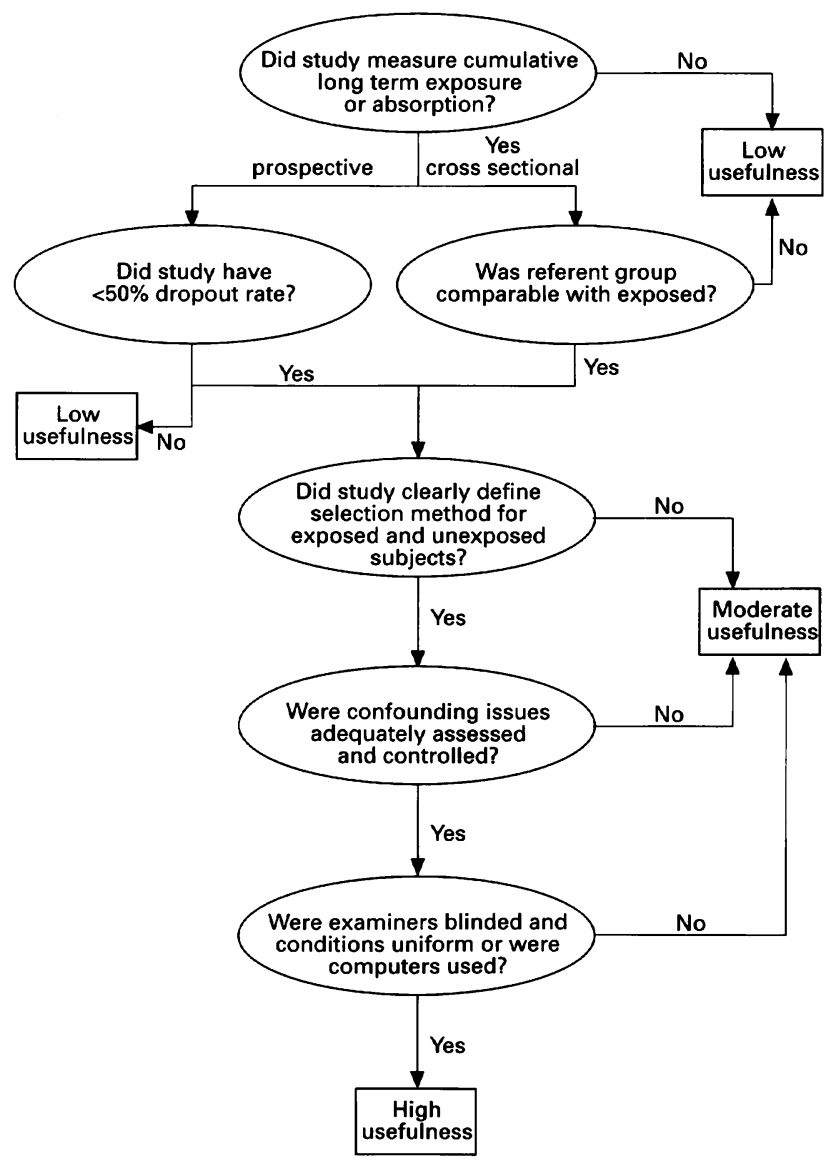

Algorithm for determining overall use of study. ditions; (c) several different examiners; and (d) assessment of reliability between testers if several examiners were used.

ASSESSMENT OF OVERALL USEFULNESS

With the above criteria, each study was assessed for its overall usefulness to assess the hypothesis that cumulative exposure to low to moderate levels of lead causes decreased neurobehavioural test performance in adults (figure). Slightly different criteria were used for prospective and cross sectional studies. A study was considered of little usefulness if it did not use a measure of cumulative exposure or absorption as described above. Cross sectional studies that did not study comparable exposed and non-exposed populations and prospective studies that experienced higher than $50 \%$ drop out rates were also considered of little usefulness, even if they used a cumulative exposure measurement. To be considered highly useful, a study had to meet the above criteria and also clearly define selection methods for exposed and non-exposed subjects, fully assess potential confounding variables, and use test conditions that were standardised and blinded to exposure. Studies not meeting these additional criteria were considered moderately useful.

\section{Results}

A total of 21 unique studies were identified from 28 published manuscripts. Eleven manuscripts were identified from the literature search, and an additional 17 papers were identified from references cited in those 11 papers. When more than one paper was published from a single cross sectional study, only one paper was selected for entry into the tables, but all papers were used in extracting study characteristics. Similarly, preliminary papers published from prospective studies were excluded unless they had significantly different conclusions or data analysis compared with the final paper-for example, Baker et al, 1984 and 1985. ${ }^{33} 34$ The total number of study participants in the 21 studies ranged from nine to 708 (table 1 ).

Most studies ( $n=16$ ) used a cross sectional design and a non-exposed comparison group (table 2). Most studies controlled for age $(n=20)$, sex $(n=19)$, and educational level $(n=16)$ by either matching or adjustment. Seven studies had similar group means for age and four studies had similar means for education without describing the method of control. In 12 studies the mean or median duration of exposure was greater than three years; in five it was less than three years, and four studies did not report duration of exposure.

Only three studies used a direct measure of cumulative exposure to or dose of lead; in another two studies duration of exposure was used as a measure of exposure in the analysis. The remaining 16 studies did not use a measure of cumulative exposure or dose by our criteria.

The average blood lead concentration in 
Table 1 Published studies of adult neurobehavioural test performance associated with exposure to inorganic lead, 1976 to the present

\begin{tabular}{|c|c|c|c|}
\hline Reference & Design & Sample size & Author's conclusions (excerpts from abstracts) \\
\hline Milburn et al ${ }^{1 n}$ & Cross sectional & $\begin{array}{l}16 \text { Exposed, } \\
15 \text { non-exposed }\end{array}$ & $\begin{array}{l}\text { "The three performance tests revealed no differences between the exposed and the non- } \\
\text { exposed groups." }\end{array}$ \\
\hline Repko et al ${ }^{17}$ & Cross sectional & $\begin{array}{l}85 \text { Exposed, } \\
55 \text { non-exposed }\end{array}$ & $\begin{array}{l}\text { ". deficits in visual reaction time ... were adversely affected by low-level absorption. No } \\
\text { differences were noted in the strength, eye-hand coordination, or other psychological/social } \\
\text { measures." }\end{array}$ \\
\hline Grandjean et $a l^{\text {ik }}$ & Cross sectional & $\begin{array}{l}42 \text { Exposed, } \\
22 \text { non-exposed }\end{array}$ & $\begin{array}{l}\text { "Significant differences ... concerning long-term memory, verbal and visuospatial abstraction, } \\
\text { and psychomotor speed." }\end{array}$ \\
\hline Haenninen et al ${ }^{10}$ & Cross sectional & $\begin{array}{l}49 \text { Exposed, } \\
24 \text { non-exposed }\end{array}$ & $\begin{array}{l}\text { "A significant relationship between impaired psychological performance and lead uptake } \\
\text { within the exposed group. The performances that were most affected by lead depended on } \\
\text { visual intelligence and visual-motor function." }\end{array}$ \\
\hline Valciukas et $a l^{2 w}$ & Cross sectional & $\begin{array}{l}90 \text { Exposed, } \\
25,99 \text { and } 93 \\
\text { non-exposed }\end{array}$ & $\begin{array}{l}\text { "Secondary lead smelter workers showed significantly poorer performance scores than the } \\
\text { nonexposed control groups." Decreased performance on block design, digit symbol, } \\
\text { embedded figures, and Santa Ana (both hands). }\end{array}$ \\
\hline Valciukas et $a l^{21}$ & Cross sectional & $\begin{array}{l}90,28 \text { and } 23 \\
\text { Exposed, } \\
265 \text { non-exposed }\end{array}$ & $\begin{array}{l}\text { "A significant association between performance test scores and increased lead absorption } \\
\text { was found ... It is concluded that workers exposed to lead at levels considered 'safe' } \\
\text { might be at risk of developing brain dysfunction with long term exposure." }\end{array}$ \\
\hline Johnson et al :2 & Cross sectional & $\begin{array}{l}209 \text { and } 234 \\
\text { exposed, } 126 \text { and } \\
139 \text { non-exposed }\end{array}$ & $\begin{array}{l}\text { "Smelter groups, when compared with community groups, showed: lengthened choice } \\
\text { reaction time in the order of } 10 \text { percent ..." }\end{array}$ \\
\hline Arnvig et al ${ }^{33}$ & Cross sectional & $\begin{array}{l}9 \text { Exposed, } \\
0 \text { non-exposed }\end{array}$ & $\begin{array}{l}\text { "Intelligence tests indicated normal intellectual potential, but memory, attention, } \\
\text { concentration and psychomotor performance were severely impaired." }\end{array}$ \\
\hline Hogstedt et al ${ }^{14}$ & Cross sectional & $\begin{array}{l}49 \text { Exposed, } \\
27 \text { non-exposed }\end{array}$ & $\begin{array}{l}\text { "The exposed group performed less well in } 11 \text { of } 14 \text { non-verbal tests, and there were } \\
\text { significant differences in tests of memory and reaction time." }\end{array}$ \\
\hline Campara et al ${ }^{15}$ & Cross sectional & $\begin{array}{l}40 \text { Exposed, } \\
20 \text { non-exposed }\end{array}$ & $\begin{array}{l}\text { "The group of workers with the highest } \mathrm{PbB} \text { levels showed significantly poorer performance } \\
\ldots \text { the poorer performance was mainly due to an impairment of general functioning and } \\
\text { only to some extent to a deterioration in specific functions." }\end{array}$ \\
\hline Jeyaratnam et al ${ }^{2 n}$ & Cross sectional & $\begin{array}{l}49 \text { Exposed, } \\
36 \text { non-exposed }\end{array}$ & $\begin{array}{l}\text { "The performance of the lead workers was found to be significantly poorer for digit symbol, } \\
\text { Bourdon-Wiersma, trail making test (part A), Santa Ana test, flicker fusion and simple } \\
\text { reaction time." }\end{array}$ \\
\hline Williamson and $\mathrm{Teo}^{2^{-}}$ & Cross sectional & $\begin{array}{l}59 \text { Exposed, } \\
59 \text { non-exposed }\end{array}$ & $\begin{array}{l}\text { "Most neurobehavioural functions tested showed some impairment in the lead workers. } \\
\text { Multiple linear regression analysis showed that performance on the sensory store memory } \\
\text { test alone was significantly related to exposure." }\end{array}$ \\
\hline Ryan et al ${ }^{2 s}$ & Cross sectional & $\begin{array}{l}288 \text { Exposed, } \\
181 \text { non-exposed }\end{array}$ & $\begin{array}{l}\text { "There is little support for the view that older adults with current blood lead levels in the low } \\
\text { to moderate range are at risk for developing significant CNS dysfunction..." }\end{array}$ \\
\hline Ahmed et al :D & Cross sectional & $\begin{array}{l}45 \text { Exposed, } \\
0 \text { non-exposed }\end{array}$ & $\begin{array}{l}\text { "Results indicated that most of the subjects studied have a comparably high } \mathrm{PbBl} \text {. They } \\
\text { also showed significantly poorer performance scores than that obtained in a previous } \\
\text { study with a group of textile workers of the same age and educational levels." }\end{array}$ \\
\hline Pasternak et al & Cross sectional & $\begin{array}{l}24 \text { Exposed, } \\
29 \text { non-exposed }\end{array}$ & $\begin{array}{l}\text { "We demonstrated a significant difference from controls in measures of psychomotor speed, } \\
\text { motor strength and verbal memory." }\end{array}$ \\
\hline Stollery et al "I & Cross sectional & $\begin{array}{l}91 \text { Exposed, } \\
0 \text { non-exposed }\end{array}$ & $\begin{array}{l}\text { "Workers with high blood lead concentrations showed clear impairment of sensory motor } \\
\text { functions in the absence of correspondingly strong evidence for impaired processing and } \\
\text { memory functions." }\end{array}$ \\
\hline Mantere et al ?: & Prospective & $\begin{array}{l}11 \text { Exposed, } \\
10 \text { non-exposed }\end{array}$ & $\begin{array}{l}\text { "Although the impairment of the lead workers' performance was rather slight and the } \\
\text { dispersion in the psychological changes was wide, it was evident that some higher nervous } \\
\text { functions were affected by lead levels above }(30 \mu \mathrm{g} / \mathrm{dl}) . \text {." }\end{array}$ \\
\hline Baker et al ${ }^{33}$ & Prospective & $\begin{array}{l}99 \text { Exposed, } \\
61 \text { non-exposed }\end{array}$ & $\begin{array}{l}\text { "Workers with blood lead concentrations between } 40 \text { and } 60 \mu \mathrm{g} / \mathrm{dl} \text { showed impaired } \\
\text { performance on tests of verbal concept formation, visual/motor performance, memory } \\
\text { and mood." }\end{array}$ \\
\hline Baker et al ${ }^{34}$ & Prospective & $\begin{array}{l}36 \text { Exposed, } \\
14 \text { non-exposed }\end{array}$ & $\begin{array}{l}\text { "This investigation confirms the importance of compliance with workplace standards } \\
\text { designed to lower exposures to ensure that individual blood lead concentrations remain } \\
\text { below } 50 \mu \mathrm{g} / \mathrm{dl} . "\end{array}$ \\
\hline Yokoyama et al ${ }^{35}$ & Prospective & $\begin{array}{l}17 \text { Exposed, } \\
11 \text { non-exposed }\end{array}$ & $\begin{array}{l}\text { "Psychological performance was significantly affected by lead absorption in the first } \\
\text { examination, resulting in a reduction in score on picture completion at the BPb level of } \\
40-46 \mu \mathrm{g} / \mathrm{dl} \text {." }\end{array}$ \\
\hline Stollery et al & Prospective & $\begin{array}{l}70 \text { Exposed, } \\
0 \text { non-exposed }\end{array}$ & $\begin{array}{l}\text { "The primary psychological profile of lead impairment is one of sensory motor slowing } \\
\text { coupled with difficulties in remembering incidental information." }\end{array}$ \\
\hline
\end{tabular}

the most exposed groups varied from $27 \cdot 8$ $\mu \mathrm{g} / \mathrm{dl}$ to $68 \cdot 3 \mu \mathrm{g} / \mathrm{dl}$, whereas most nonexposed groups had blood lead concentrations less than $20 \mu \mathrm{g} / \mathrm{dl}$ (table 3). Several studies (Grandjean et al, Baker et al, Ryan et al) combined workers with very short ( $<6$ months) and very long ( $>20$ years) duration of exposure without controlling for the effects of duration of exposure in the data analysis. ${ }^{18} 2833$ Many studies that did not use computer tests either did not blind examiners or did not provide any information on this issue.

Most exposed groups were recruited from battery plants or lead smelters (table 4). Most studies did not explicitly report selection and recruitment methods or participation rates among exposed workers. The source of nonexposed groups varied; in nine studies, the non-exposed group was comparable with the exposed group (similar industries, same factory or union), whereas in six, the non- exposed group was likely to differ from exposed subjects on such important factors as socioeconomic or educational background (community volunteers, male nurses). Two studies did not provide enough information on the selection of non-exposed subjects to permit such a judgment. Control of confounding variables also varied from study to study. Although most studies reported no significant overall differences between groups with respect to age and ability before exposure, few studies controlled for these variables in regression models. Thus, residual confounding may still have been present. Few studies assessed potential confounding by alcohol consumption or earlier exposure to neurotoxins, although these factors are unlikely to have resulted in significant confounding. All studies that controlled for ability before exposure used education for this purpose. 
Table 2 A summary of study characteristics considered to be useful in evaluating the neurobehavioural effects of inorganic lead in adults

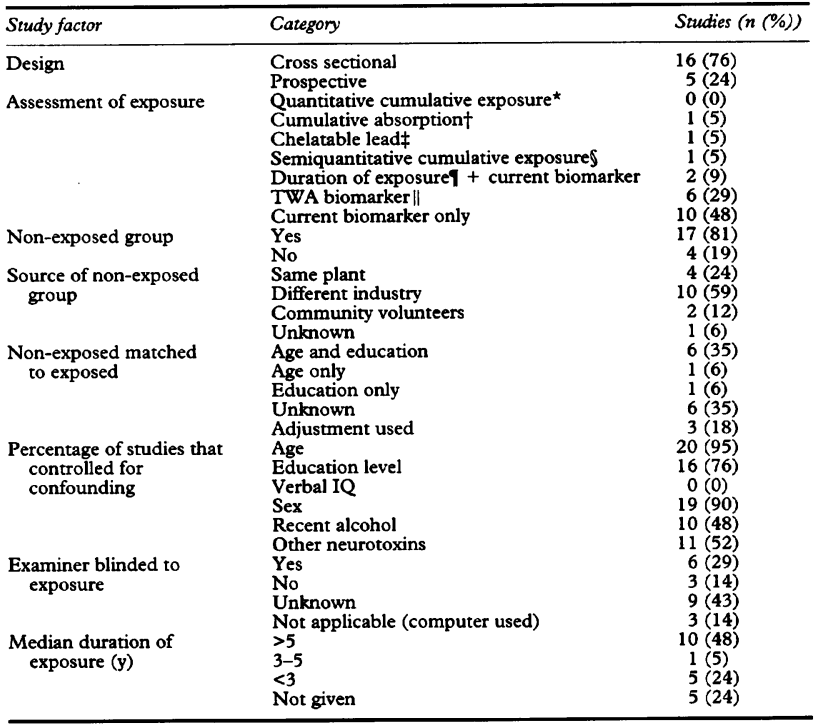

^Estimated by product of time weighted average air lead concentrations and duration of exposure.

tEstimated by product of time weighted average blood lead concentrations and duration of

exposure. †Urinary lead excretion for 24 hours after $20 \mathrm{mg} / \mathrm{kg}$ IV EDTA.
§Product of ordinal ranking of intensity of exposure based on expert opinion and duration of exposure.

Current biomarker = blood lead, zinc protoporphyrin, or aminolevulinic acid

"Time weighted average blood lead, zinc protoporphyrin, or aminolevulinic acid, obtained at time of neurobehavioural test, and averaged over a range of one to nine years before test.

Few studies used a measure of cumulative exposure or absorption. Three of the five studies that used such a measure were thought to be of moderate usefulness (Valciukas et al, Yokoyama et al, and Stollery et al)..$^{203536}$ Although another two studies (Williamson and Teo, Pasternak et al) used a measure of cumulative exposure or absorption, the duration of exposure among workers was thought to be too short to adequately separate cumulative from concurrent effects. Specifically, in the study of Williamson and $\mathrm{Teo}$, the median duration of exposure was 2.08 years and in the study of Pasternak et al the mean duration of exposure was $2 \cdot 80$ years ( $77 \%$ of the workers were exposed for less than three years. $)^{27} 30$

After ranking the studies on the basis of overall usefulness, examination of comparisons performed and associations found showed several notable findings (table 5). Firstly, among the five studies that used a measure of cumulative exposure to or absorption of lead, neurobehavioural test performance was more strongly associated with current rather than cumulative measures. Secondly, the most rigorous studies generally found fewer significant differences in neurobehavioural function than less rigorous studies. Finally, dexterity (17 out of 21 studies) and executive or psychomotor (11 out of 21) were the neuropsychological domains most frequently associated with any measure of exposure to or absorption of lead.

\section{Discussion}

The scientific literature offers little evidence that cumulative exposure to low to moderate levels of inorganic lead affects neurobehavioural test performance in adults. Notably, the data are also insufficient to conclude that such exposure does not affect the adult CNS. The main reason for this lack of useful evidence is that all but five of the published studies failed to use an estimate of cumulative exposure to or absorption of lead. Although the studies that used current measures reported associations between exposure to lead and neurobehavioural function, associations with recent exposure may be transient or reversible and therefore of limited significance to public health. Two of the five studies that used cumulative measures (Valciukas et al and Yokoyama et al) found that neurobehavioural test performance was associated with cumulative exposure and chelatable lead, respectively, in the domains of visuomotor function, dexterity, and formation of visual concept $\$ .^{20}{ }^{35}$ Stollery et al, on the other hand, did not find any association between duration of exposure and neurobehavioural performance. ${ }^{36}$ The three studies differed greatly on a variety of study design features, so it is difficult to account for this inconsistency in results. In general, fewer and weaker associations were found between cumulative measures and test scores than between current measures and test scores. Unfortunately, even those studies that used cumulative measures primarily reported analyses with current measures.

Three studies estimated exposure as the time weighted average of blood lead concentrations obtained during the course of employment (Haenninen et al, Hogstedt et al, Ryan et al)..$^{1928}$ Although such a measure yields an average intensity of absorption, it does not account for duration of exposure. As the exposed subjects had varying durations of exposure, average intensity was a poor relative estimate of cumulative absorption. For example, younger workers, often employed in the most highly exposed jobs, would have higher time weighted average blood lead concentrations but lower cumulative absorption of lead than older, long term workers whose average intensity of exposure may have been lower. The lack of association between time weighted average blood lead and age in Haenninen et al ${ }^{19}$ emphasises this point; age is generally correlated with cumulative exposure and lead in cortical bone. ${ }^{715}$ Thus, associations such as those found by Haenninen $e t a l$, if causal, may be due to the effects of relatively short term, not cumulative exposure.

Several otherwise well designed studies (Stollery et al and Campara et al) found associations between measures of current blood lead and decrements in neurobehavioural test performance..$^{251}$ As current concentrations of blood lead are more likely to reflect recent exposures, as stated previously, the associations found may be due to an acute rather than cumulative effect of lead. In other studies, confounding by capability before exposure or age could account for the associations. 
Table 3 Exposure variables used and characteristics of data collection considered important in assessment of the use of studies that evaluated the neurobehavioural effects of inorganic lead in adults

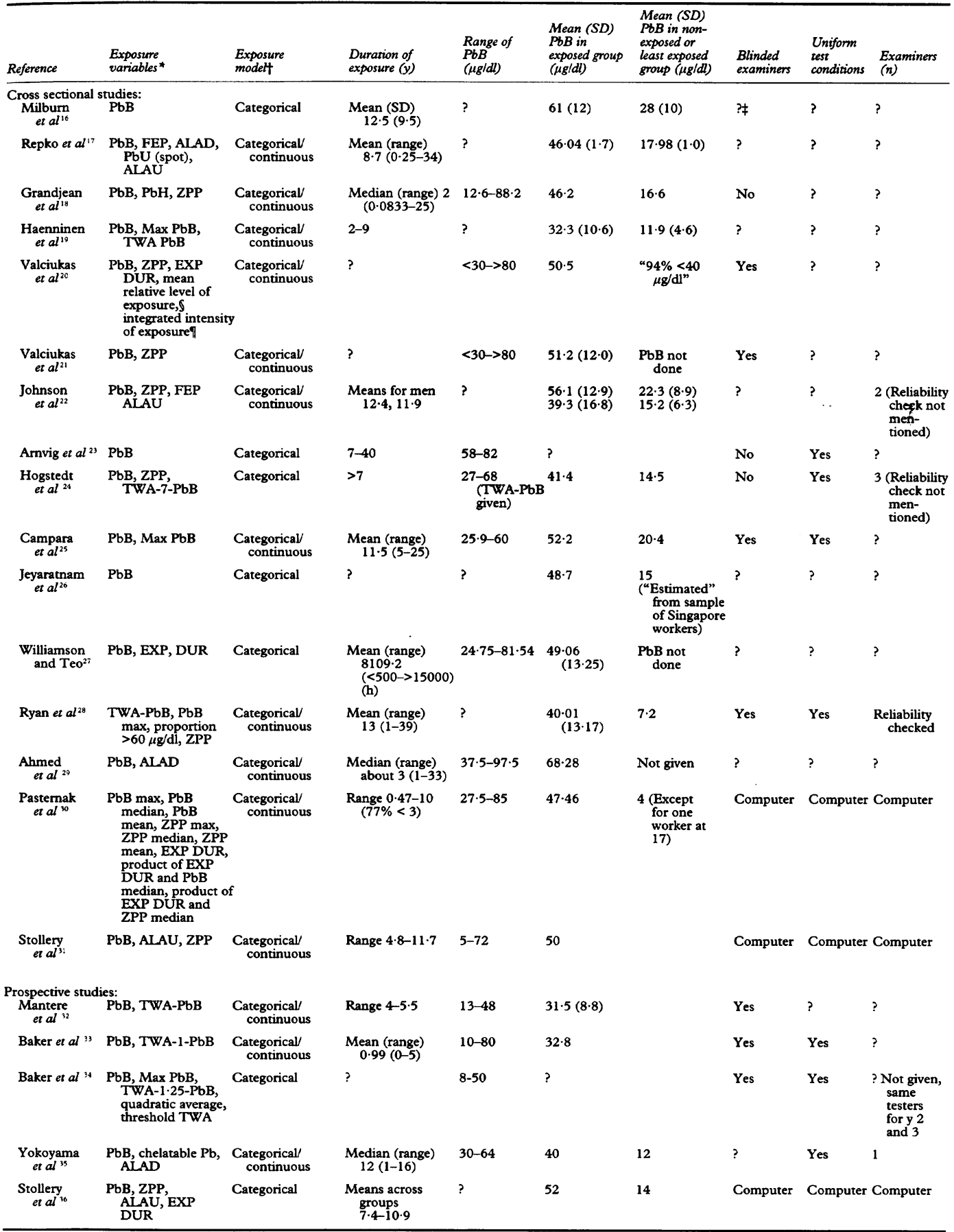

\# $\mathrm{PbB}=$ current blood lead concentration; FEP = free erythrocyte protoporphyrin; $\mathrm{ALAD}=$ amino levulinic acid dehydratase; $\mathrm{PbU}=$ urinary lead concentration; ALAU = urinary aminolevulinic acid concentration; $\mathrm{PbH}=$ hair lead concentration; $\mathrm{ZPP}=$ zinc protoporphyrin concentration; $M$ ax = maximum; TWA = time weighted average- a number after TWA indicates the number of years averaged; EXP DUR = exposure duration; chelatable Pb $=24 \mathrm{hour}$ urinary excretion of lead after $20 \mathrm{mg} / \mathrm{kg}$ dose of EDTA.

$\dagger$ Indicates whether exposure variable was used as a continuous variable or analysed as a categorical variable by separating subjects into groups based on exposure levels.

¥ Indicates no information reported on this characteristic.

Defined as the mean of ratings of intensity of exposure from 1 to 3 for each job held as determined by an industrial hygienist.

Defined as the sum of the products of the rating of intensity of exposure for each job and the duration of employment in each job. 
Table 4 Sources of exposed and non-exposed groups, percentage participation, and methods of control for confounding variables in twenty-one studies that evaluated the neurobehavioural effects of inorganic lead in adults

\begin{tabular}{|c|c|c|c|c|c|c|c|}
\hline \multirow[b]{2}{*}{ Reference } & \multicolumn{3}{|l|}{ Selection issues } & \multicolumn{4}{|c|}{ Method of control of confounders } \\
\hline & Study group & $\begin{array}{l}\text { Participation } \\
\text { (\%, and } \\
\text { follow up) }\end{array}$ & Control group & Age & $\begin{array}{l}\text { Ability } \\
\text { before exposure }\end{array}$ & Alcohol & $\begin{array}{l}\text { Previous } \\
\text { exposures }\end{array}$ \\
\hline \multicolumn{8}{|c|}{ Cross sectional studies: } \\
\hline $\begin{array}{l}\text { Milburn } \\
\text { et al }{ }^{16}\end{array}$ & $\begin{array}{l}\text { Male workers from lead acid } \\
\text { battery plant }\end{array}$ & ?* & $\begin{array}{l}\text { Male workers from } \\
\text { plastics department } \\
\text { of same company }\end{array}$ & Unknownt & $?$ & $?$ & ? \\
\hline Repko et al ${ }^{17}$ & $\begin{array}{l}\text { Volunteers from one of two } \\
\text { storage battery plants }\end{array}$ & ? & $\begin{array}{l}\text { Same locations; controls } \\
\text { were younger, more } \\
\text { women, more college } \\
\text { graduates }\end{array}$ & Matched & $\begin{array}{r}\text { Matched on } \\
\text { education }\end{array}$ & $?$ & Unknown \\
\hline $\begin{array}{l}\text { Grandjean } \\
\text { et al }\end{array}$ & $\begin{array}{l}\text { Workers from five different } \\
\text { factories; selection method } \\
\text { not stated }\end{array}$ & $?$ & $\begin{array}{l}\text { Controls from food oil } \\
\text { processing mill }\end{array}$ & Unknown & Unknown & Unknown & Unknown \\
\hline $\begin{array}{l}\text { Haenninen } \\
\quad \text { et al }\end{array}$ & $\begin{array}{l}\text { Workers from two storage } \\
\text { battery plants or railway } \\
\text { machine shop; selection } \\
\text { method not stated }\end{array}$ & $?$ & $\begin{array}{l}\text { New employees of one } \\
\text { of the battery plants, } \\
\text { electrical workers }\end{array}$ & $\begin{array}{l}\text { Matched, } \\
\text { restricted }\end{array}$ & $\begin{array}{r}\text { Matched on } \\
\text { education }\end{array}$ & $?$ & Restricted \\
\hline $\begin{array}{l}\text { Valciukas } \\
\text { et } a^{20}\end{array}$ & $\begin{array}{l}\text { Workers from secondary } \\
\text { lead smelter in Los } \\
\text { Angeles }\end{array}$ & $?$ & $\begin{array}{l}\text { Three control groups: } \\
\text { steelworkers from } \\
\text { same union in Los } \\
\text { Angeles, papermill } \\
\text { workers from Virginia, } \\
\text { Wisconsin farmers }\end{array}$ & $\begin{array}{l}\text { Matched, } \\
\text { adjusted }\end{array}$ & $\begin{array}{l}\text { Matched, } \\
\text { adjusted } \\
\text { on education }\end{array}$ & $?$ & $?$ \\
\hline $\begin{array}{l}\text { Valciukas } \\
\qquad e t a l^{2 !}\end{array}$ & $\begin{array}{l}\text { Cable splicers, cable } \\
\text { manufacturers from New } \\
\text { York; secondary lead } \\
\text { smelter workers from } \\
\text { Los Angeles; selection } \\
\text { method not stated }\end{array}$ & $?$ & $\begin{array}{l}\text { Residents of Michigan } \\
\text { screened for PCB's; } \\
\text { no lead concentrations } \\
\text { measured }\end{array}$ & Adjusted & $\begin{array}{r}\text { Adjusted on } \\
\text { education }\end{array}$ & .. & $?$ \\
\hline $\begin{array}{l}\text { Johnson } \\
\text { et } a l^{22}\end{array}$ & $\begin{array}{l}\text { Randomly selected men, all } \\
\text { women from lead and } \\
\text { zinc smelters }\end{array}$ & $\begin{array}{l}100 \% \text { Of women } \\
\text { ? men }\end{array}$ & $\begin{array}{l}\text { Volunteers from nearby } \\
\text { communities, one of } \\
\text { which had } \\
\text { environmental lead } \\
\text { exposure }\end{array}$ & Matched & $?$ & Restricted & $?$ \\
\hline Arnvig et $a l^{23}$ & $\begin{array}{l}\text { Selected on basis of } \\
\text { presumed high exposure } \\
\text { from battery plant }\end{array}$ & $?$ & $\begin{array}{l}\text { Scores compared to } \\
\text { reference data from } \\
\text { orthopedic and other } \\
\text { groups }\end{array}$ & $?$ & $?$ & $?$ & $?$ \\
\hline $\begin{array}{l}\text { Hogstedt } \\
\text { et } a^{24}\end{array}$ & $\begin{array}{l}\text { Recruited from occupational } \\
\text { surveillance laboratory; } \\
\text { worked in secondary lead } \\
\text { smelters and battery } \\
\text { factories }\end{array}$ & $84 \%$ & $\begin{array}{l}\text { Controls selected from } \\
\text { same laboratory; } \\
\text { more shift workers in } \\
\text { control group } \\
(55 \% \text { v } 24 \%)\end{array}$ & Unknown & $\begin{array}{l}\text { Restricted } \\
\text { (pre-exposure } \\
\text { tests available } \\
\text { and equal } \\
\text { for } 37 \% \text { of cases } \\
\text { and } 44 \% \text { of } \\
\text { controls) }\end{array}$ & Unknown & Unknown \\
\hline $\begin{array}{l}\text { Campara } \\
\text { et al }\end{array}$ & $\begin{array}{l}\text { Selected on basis of recent } \\
\text { and maximal blood lead } \\
\text { values; worked at storage } \\
\text { battery plant }\end{array}$ & $\begin{array}{l}11 \% \text { Of a } \\
\text { population of } \\
350 \text { exposed } \\
\text { workers; no } \\
\text { refusals } \\
\text { mentioned }\end{array}$ & $\begin{array}{l}\text { Control group male } \\
\text { nurses from local } \\
\text { hospital }\end{array}$ & Matched & $\begin{array}{r}\text { Matched on } \\
\text { education }\end{array}$ & Restricted & Restricted \\
\hline $\begin{array}{l}\text { Jeyaratnam } \\
\text { et } \text { al }^{26}\end{array}$ & $\begin{array}{l}\text { Workers from Singapore } \\
\text { plant that used lead } \\
\text { stabilisers in PVC } \\
\text { production; selection } \\
\text { method not given }\end{array}$ & $?$ & $\begin{array}{l}\text { Controls selected from } \\
\text { other industrial } \\
\text { workers in Singapore, } \\
\text { selection method } \\
\text { not given }\end{array}$ & $\begin{array}{l}\text { Unknown } \\
\text { (statistically } \\
\text { significant } \\
\text { difference) }\end{array}$ & $\begin{array}{r}\text { Matched on } \\
\text { education }\end{array}$ & $?$ & $?$ \\
\hline $\begin{array}{l}\text { Williamson } \\
\text { and } \mathrm{Teo}^{27}\end{array}$ & $\begin{array}{l}\text { Male workers from either } \\
\text { battery factory or } \\
\text { secondary lead smelter; } \\
\text { selection method not given }\end{array}$ & $?$ & $\begin{array}{l}\text { Source of controls not } \\
\text { given; } 17 \% \text { of control } \\
\text { group women }\end{array}$ & Matched & $\begin{array}{l}\text { Matched on } \\
\text { education }\end{array}$ & $\begin{array}{l}\text { Matched } \\
\text { acute and } \\
\text { chronic }\end{array}$ & $?$ \\
\hline Ryan et al ${ }^{28}$ & $\begin{array}{l}\text { Randomly selected from } \\
\text { three battery plants }\end{array}$ & $67 \%$ & $\begin{array}{l}\text { Randomly selected from } \\
\text { car and lorry chassis } \\
\text { plant; } 33 \% \text { of controls } \\
\text { screened out by lead } \\
\text { concentrations }\end{array}$ & Matched & $\begin{array}{l}\text { Matched, } \\
\text { adjusted on } \\
\text { education }\end{array}$ & $\begin{array}{l}\text { Matched, } \\
\text { restricted }\end{array}$ & Restricted \\
\hline $\begin{array}{l}\text { Ahmed } \\
\text { et } \text { al }^{29}\end{array}$ & $\begin{array}{l}\text { Randomly selected from } \\
\text { Alexandria traffic } \\
\text { controllers }\end{array}$ & $?$ & $\begin{array}{l}\text { Unpublished data on } \\
\text { textile workers from } \\
\text { another study used as } \\
\text { reference }\end{array}$ & Unknown & Unknown & $?$ & $?$ \\
\hline $\begin{array}{l}\text { Pasternak } \\
\quad e t a l^{30}\end{array}$ & $\begin{array}{l}\text { Volunteers from electrical } \\
\text { component factory }\end{array}$ & $\begin{array}{l}\text { ? ("Most” } \\
\text { workers; } \\
\text { numbers of } \\
\text { exposed } \\
\text { workers not } \\
\text { known) }\end{array}$ & $\begin{array}{l}\text { Recruited from different } \\
\text { area of same plant }\end{array}$ & Unknown & Unknown & $\begin{array}{l}\text { Unknown } \\
\text { (high } \\
\text { numbers of } \\
\text { non- } \\
\text { responders } \\
\text { to questionna } \\
\text { on this) }\end{array}$ & $\begin{array}{l}? \\
\text { aire }\end{array}$ \\
\hline $\begin{array}{l}\text { Stollery } \\
\text { et } a l^{31}\end{array}$ & $\begin{array}{l}\text { Recruited from battery and } \\
\text { printing plants }\end{array}$ & $?$ & No control group & Adjusted & $\begin{array}{l}\text { Adjusted for age } \\
\text { left school }\end{array}$ & $\begin{array}{l}\text { High group } \\
\text { had } \\
\text { significantly } \\
\text { higher } \\
\text { recent intake }\end{array}$ & ? \\
\hline
\end{tabular}

* Indicates information was not reported.

† Unknown indicates study reported similar group means, but method of control was not reported.

¥ Despite matching, substantial difference remained between groups. 
Table 4 continued from page 8

\begin{tabular}{|c|c|c|c|c|c|c|c|}
\hline \multirow[b]{2}{*}{ Reference } & \multicolumn{3}{|l|}{ Selection issues } & \multicolumn{4}{|c|}{ Method of control of confounders } \\
\hline & Study group & $\begin{array}{l}\text { Participation } \\
\text { ( } \% \text {, and } \\
\text { follow up) }\end{array}$ & Control group & Age & $\begin{array}{l}\text { Ability } \\
\text { before exposure }\end{array}$ & Alcohol & $\begin{array}{l}\text { Previous } \\
\text { exposures }\end{array}$ \\
\hline \multicolumn{8}{|c|}{ Prospective studies: } \\
\hline $\begin{array}{l}\text { Mantere } \\
\text { et al }\end{array}$ & $\begin{array}{l}\text { Recruited from new } \\
\text { employees at battery } \\
\text { plant }\end{array}$ & \multirow{2}{*}{$\begin{array}{l}100 \% \\
27 \% \text { At } 1 \mathrm{y} \\
18 \% \text { At } 2 \mathrm{y} \\
12 \% \text { At } 4 \mathrm{y} \\
91 \% \text {. } \\
\mathbf{4 3} \% \text { At } 1 \mathrm{y} \\
38 \% \text { At } 2 \mathrm{y}\end{array}$} & $\begin{array}{l}\text { Recruited from cable } \\
\text { and electronics plants }\end{array}$ & Unknown & $?$ & $?$ & Unknown \\
\hline Baker et al " & Recruited from foundry & & $\begin{array}{l}\text { Controls recruited from } \\
\text { adjacent assembly } \\
\text { plant }\end{array}$ & Adjusted & $\begin{array}{l}\text { Adjusted for } \\
\text { education }\end{array}$ & Restricted & Restricted \\
\hline Baker et $a^{34}$ & Recruited from foundry & See above & $\begin{array}{l}66 \% \text { Of exposed, } 78 \% \\
\text { of controls lost from } \\
\text { 1st to 3rd y }\end{array}$ & Adjusted & $\begin{array}{l}\text { Adjusted for } \\
\text { education }\end{array}$ & Restricted & Restricted \\
\hline $\begin{array}{l}\text { Yokoyama } \\
\text { et } \text { al }^{35}\end{array}$ & $\begin{array}{l}\text { Recruited from gun metal } \\
\text { foundry }\end{array}$ & $?$ & $\begin{array}{l}\text { Steel foundry workers at } \\
\text { same factory. Although } \\
\text { difference not significant, } \\
\text { controls were younger } \\
\text { (median } 43 v 49) \text { and } \\
\text { drank less alcohol }(155 \\
v 200 \mathrm{ml} / \text { week) }\end{array}$ & Unknown & Unknown & Unknown & $\begin{array}{l}\text { No } \\
\text { previous } \\
\text { exposure } \\
\text { to lead }\end{array}$ \\
\hline $\begin{array}{l}\text { Stollery } \\
\text { et } \text { al }^{3 \kappa}\end{array}$ & $\begin{array}{l}\text { Recruited from battery and } \\
\text { printing plants }\end{array}$ & $\begin{array}{l}77 \% \text { Of initial } \\
\text { cohort at eight } \\
\text { months }\end{array}$ & $\begin{array}{l}\text { Young, high exposure } \\
\text { workers lost } \\
\text { disproportionately }\end{array}$ & Adjusted & $\begin{array}{l}\text { Adjusted for } \\
\text { age left school }\end{array}$ & $?$ & Unknown \\
\hline
\end{tabular}

Age is a strong predictor of neurobehavioural performance, but it was controlled in most studies only by matching means or medians. This may still allow residual confounding if the range of ages is wider in the exposed than non-exposed subjects, as was true in several of the studies (Repko et al and Haenninen et al). ${ }^{1719}$ As neurobehavioural test performance remains fairly stable until advanced age (50-65 depending on the test), the older workers from the group with the more extreme range are likely to exert a strong influence on the associations found.

Control for intellectual ability before exposure, especially in cross sectional studies, is particularly difficult. Nearly all studies used education, either to match group means in group comparisons, or as a covariate in multiple linear regression models. Several studies still found substantial differences between groups in vocabulary scores. This suggests that education may be an inadequate control for intellectual ability before exposure. For example, Baker et al found that exposure to lead had a strong negative association with the vocabulary test score. ${ }^{33}$ This may either represent a causal association or that less capable workers are most likely to work in the most highly exposed jobs. To the extent that the vocabulary score reflects overall intellectual ability before exposure, the difference found in this measure limits the inferences that can be made from other associations found.

Study results were not pooled for the purposes of a quantitative meta-analysis because of differences in exposure and outcome variables among studies. Comparison of data from studies that used the same neurobehavioural tests showed that test scores had greater variability between studies than between exposed and non-exposed groups within the same study (data not shown). This variation could either be due to unassessed differences in cumulative exposure (the differences in average blood lead concentrations were not significant) or to differences in age, ability before exposure, or test methods among the study populations. These possible explanations are indistinguishable without accurate cumulative exposure measures.

The distinction between effects of cumulative and recent exposure has important public health implications. It is possible that subclinical neurobehavioural dysfunction associated with short term recent exposure may be reversible if exposure ceases and blood lead concentrations decline. Decreased neurobehavioural test performance associated with cumulative lead exposure or absorption is more likely to be irreversible, and hence may contribute to premature dementia and neurological dysfunction as the subject ages.

Future studies will need to incorporate design features that allow more accurate distinction between the acute and chronic effects of exposure to lead. To detect chronic, irreversible effects, one approach would be a prospective study of workers over the age of 50 with many years of exposure to lead. Such a design may be compromised by a survivor effect, in that the workers with symptomatic neurobehavioural effects may have left the workplace before the age of 50 . On the other hand, this design can assess the change in neurobehavioural function over time, allow the remaining workers to function as their own controls, and avoid several other biases inherent in a cross sectional study of a population of older workers. Evaluation of workers with similar current concentrations of blood lead but different levels of cumulative exposure would help to distinguish the relative contributions of cumulative exposure (bone lead) and current internal dose (blood lead). Measurement of changes in bone lead, bioavailable lead (chelatable lead), and blood lead over time would help to define whether remobilisation of stores of bone lead in older people contributes to ongoing neurotoxicity. An alternative study design would be a 
Table 5 List of neurobehavioural tests that showed significant differences between groups, or significant association with exposure variables (studies listed in approximate order of overall usefulness)

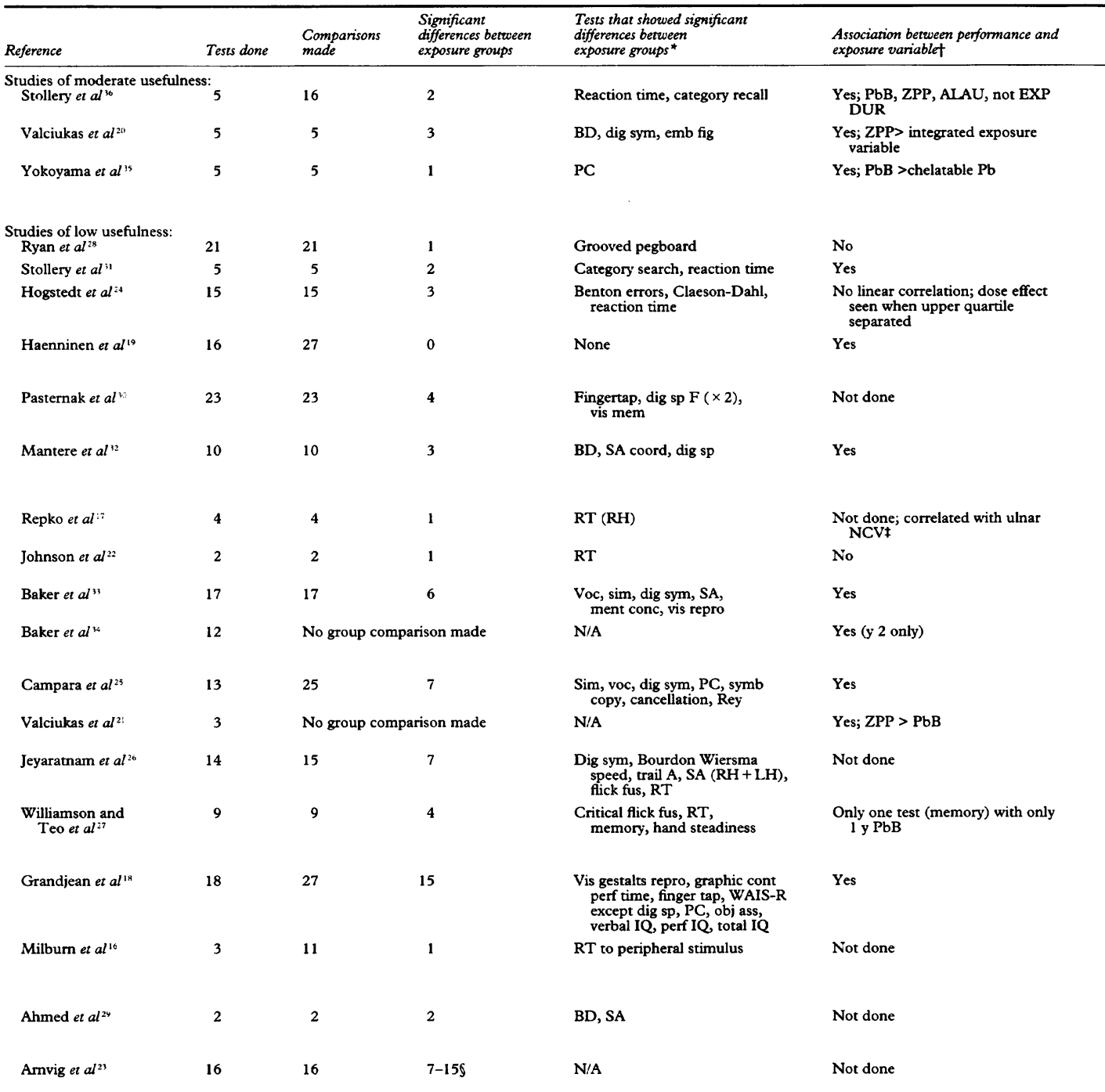

$\star \mathrm{BD}=$ block design subtest of Wechsler adult intelligence scale (WAIS); dig sym = digit symbol substitution subtest of WAIS; emb fig = embedded figures; PC = picture completion subtest of WAIS; RT = reaction time; vis mem = visual memory; dig sp = digit span $(\mathrm{F}$ indicates forward only); voc $=$ vocabulary subtest of WAIS; $\operatorname{sim}=$ similarities subtest of WAIS; SA = Santa Ana coordination test (RH/LH denotes hand tested); ment conc = mental concentration subtest of WAIS; vis repro = visual reproduction subtest of WAIS; trail $\mathrm{A} / \mathrm{B}=$ Trailmaking $\mathrm{A}$ or $\mathrm{B}$; flick fus = flicker fusion test; symb copy = symbol copying; paired association lrn = paired associative learning subtest of Wechsler memory scale; vis gestalts repro = visual gestalts reproduction; obj ass = object assembly subtest of WAIS; perf IQ = performance IQ.

Abbreviations as for table 3.

$\mathrm{NCV}=$ nerve conduction velocity.

Denoces range of number of tests found abnormal per individual in comparison with population standards. Because of variability of individual tests and poor comparability of non-exposed group, individual tests are not named.

randomised trial of chelation treatment and its effect on neurobehavioural function. Randomisation of workers should effectively control for important confounding variables, and the association of neurobehavioural function with changes in tissue, blood, and chelatable lead concentrations after chelation would allow inferences to be made about the reversible and irreversible effects of lead.

In summary, the current scientific literature provides inadequate evidence to conclude whether or not cumulative absorption of lead adversely affects neurobehavioural test performance in adults. The current evidence is flawed because of inadequate estimation of cumulative absorption of lead and inadequate control for age and intellectual ability before exposure. Because of the failure to estimate cumulative exposure to or absorption of lead, the published studies do not allow separation 
Tests that showed significant association *

Reaction time, category recall

BD, dig sym, emb fig

PC

\section{N/A \\ Category search, reaction time \\ Benton errors, Claeson-Dahl, reaction time}

BD, vis repro, SA

N/A

BD, SA

N/A

N/A

Voc, sim, ment conc; correlated with current $\mathrm{PbB}$, not TWA-12-PbB

Paired association Im, SA (both) correlated with several averages and current $\mathrm{PbB}$

Voc, PC, sim, DSST, card sorting

BD, dig sym, emb fig

Memory

Vis gestalts repro, graphic cont perf time, finger tap, WAIS-R except dig sp, PC
obj ass, verbal IQ perf IQ, total IQ

Domains of significant difference or association

Factors decreasing use

Dexterity, verbal memory

Visuomotor, visual concept formation, dexterity

Executive/psychomotor

Dexterity

Dexterity, executive

Memory, learning, dexterity

Visuomotor, visual learning, dexterity

Dexterity, verbal memory, visual memory

Dexterity, visuomotor

Dexterity

Dexterity

Verbal intell, visuomotor, verbal concept formation, attention, visual memory

Verbal learning, dexterity

Verbal intell, executive, memory, visual concept form, visual learning, attention

Visuomotor, visual conc form, dexterity

Dexterity, executive/psychomotor, attention' concentration

Dexterity, memory visuomotor

Verbal memory and learning, visual memory and learning, dexterity, executive, attention concentration

Attention/concentration

Executive/psychomotor, dexterity

N/A
Cumulative measure was duration of exposure, bulk of analysis directed at more recent exposure and dose measures

Percentage participation not given; alcohol ingestion not controlled; data collection not well characterised

Cumulative measure not used for categorical comparison; confounding by age, education not well controlled; selection methods not given

No cumulative measure

No cumulative measure, percentage participation not given

No cumulative measure; examiners not blinded, method of control of confounders not stated

No cumulative measure; percentage participation not given level of exposure low for $\mathrm{PbB}$; data collection not wellcharacterised

Short exposure duration; small numbers; half of exposed group underwent chelation; cumulative measure calculated but not used in regression analysis

73\% Dropout after first year; additional $54 \%$ dropout subsequent to first year; exposure duration short; no cumulative measure per se (TWA-PbB in group with similar exposure duration)

No cumulative measure; percentage participation unknown; neurobehavioural tests limited in scope

No cumulative measure; tests limited to eye-hand coordination and RT; no control for ability before exposure

No cumulative measure; strongest correlation with vocab and sim scores

No cumulative measure; dropout rate $66 \%$ exposed, $78 \%$ controls; large intergroup differences in vocabulary scores

No cumulative measure; large intergroup differences in vocabulary scores; non-exposed group not comparable

No cumulative measure; no $\mathrm{PbB}$ data on reference group; reference group not comparable to exposed groups

No cumulative measure; poor control of confounders, selection methods not stated, duration of exposure not stated but mean age of exposed 26.1 y

Poorly matched on sex; controls younger, more educated with $0.05<\mathrm{P}<0.10 ; \mathrm{PbB}$ concentrations not measured in contro group; median duration of employment for exposed group $<3 \mathrm{y}$

No cumulative measure; no control for confounders; median exposure $2 \mathrm{y}$; no description of selection or data collection methods

Lead exposed were significantly faster than non-exposed on reaction time test; no cumulative measure; small numbers; 8 of 15 non-exposed had history of lead exposure $>5 y$ before study; no control for pre-exposure ability

No cumulative measure; neurobehavioural test results not shown; control group data from different study; poor control of confounders

No cumulative measure; study design similar to case series; no control of confounders; reference group not similar of the acute and chronic effects of lead. Studies that use direct measures of cumulative absorption, such as $x$ ray fluorescence, and that use prospective designs will be necessary to adequately resolve this issue.

1 ATSDR. Toxicological profile for lead. Washington: US Department of Health and Human Services, Public Department of Health

2 Parkinson DK, Ryan C, Bromet EJ, Connell MM. A psychiatric epidemiologic study of occupational lead exposure. Am $\mathcal{F}$ Epidemiol 1986;123:261-9.
3 Zimmerman-Tansella C, Campara P, D'Andiea F Savonitto C, Tansella M. Psychological and physical complaints of subjects with low exposure to lead. Human complaints of subjects with

4 Baker EL, Feldman RG, White RF, Harley JP. The role of occupational lead exposure in the genesis of psychiatric 67(303):38-48.

5 Schottenfeld RS, Cullen MR. Organic affective illness associated with lead intoxication. Am f Psychiarry 1984; 141:1423-6.

6 Landrigan PJ, Todd AC. Direct measurement of lead in bone: a promising biomarker. $\mathscr{F} A M A$ 1994;271:239-40.

$7 \mathrm{Hu} \mathrm{H}$, Pepper L, Goldman R. Effect of repeated occupational exposure to lead, cessation of exposure, and 
chelation on levels of lead in bone. Am $\mathcal{F}$ Ind Med 1991; 20:723-35.

8 Rappaport SM. Assessment of long-term exposures to toxic substances in air. Ann Occup Hyg 1991;35:61-121.

9 Vitale LF, Joselow MM, Wedeen RP, Pawlow M. Blood lead-an inadequate measure of occupational exposure. f Occup Med 1975;17:155-6.

10 Tell I, Somervaille LJ, Nilsson U, Bensyrd I, Schütz A, Chettle DR, Scott MC, Skerfving S. Chelated lead and bone lead. Scand $\mathcal{f}$ Work Environ Health 1992;18: $113-9$.

11 Agnew J, Bolla-Wilson K, Kawas $\mathrm{CH}$, Bleecker ML. Purdue pegboard age and sex norms for people 40 years old and older. Developmental Neuropsychology 1988;4: 29-35.

12 Bleecker ML, Bolla-Wilson K, Agnew J, Meyers DA. Simple visual reaction time: sex and age differences. Simple visual reaction time: sex and age dife

13 Gade A, Mortensen EL, Bruhn P. "Chronic painters' syndrome". A reanalysis of psychological test data in a group of diagnosed cases, based on comparison with matched controls. Acta Neurol Scand 1988;77: 293-306.

14 Schwartz BS, Bolla KI, Stewart W, Ford DP, Agnew J, Frumkin H. Decrements in neurobehavioral performance associated with mixed exposure to organic and inorganic lead. $A m \mathcal{F}$ Epidemiol 1993;137:1006-21.

15 Kosnett MJ, Becker CE, Osterloh JD, Kelly TJ, Pasta DJ. Factors influencing bone lead concentration in a suburban community assessed by noninvasive $x$ ray fluorescence. JAMA 1994;271:197-203.

16 Milburn $H$, Mitran E, Crockford GW. An investigation of lead workers for subclinical effects of lead using three lead workers for subclinical effects of lead using thro

performance tests. Ann Occup Hyg 1976;19:239-49.
17 Repko JD, Jones PD, Garcia Jr. LS, Corum RC. The effects of inorganic lead on behavioral and neurologic function. Washington: US Department of Health, Education, and Welfare. National Institute of Occupational Safety and Health, 1977. (Contract No 210-75-0054.)

18 Grandjean P, Arnvig E, Beckmann J. Psychological dysfunction in lead exposed workers: relation to biological parameters of exposure. Scand $\mathcal{f}$ Work Environ Health 1978;4:295-303.

19 Haenninen $H$, Hernberg $S$, Mantere $P$, Vesanto $R$, Jalkanen M. Psychological performance of subjects with low exposure to lead. F Occup Med 1978;20:683-9.

20 Valciukas JA, Lilis R, Eisinger J, Blumberg WE, Fischbein A, Selikoff IJ. Behavioral indicators of lead neurotoxicity: results of a clinical field survey. Int Arch Occup toxicity: results of a clinical field
Environ Health $1978 ; 41: 217-36$.

21 Valciukas JA, Lilis R, Singer R, Fischbein A, Anderson HA, Glickman L. Lead exposure and behavioral changes: comparisons of four occupational groups with changes: comparisons of four occupational groups with
different levels of lead absorption. Am $\mathcal{F}$ Ind Med 1980;
1:421-6

22 Johnson BL, Burg JR, Xintaras C, Handke JL. A neurobehavioral examination of workers from a primary nonferrous smelter. Neurotoxicology 1980;1:561-81.

23 Arnvig E, Grandjean P, Beckmann J. Neurotoxic effects of heavy lead exposure determined with psychological tests. Toxicol Lett 1980;5:399-404.

24 Hogstedt C, Hane M, Agrell A, Bodin L. Neuropsychological test results and symptoms among workers with well-defined long-term exposure to lead. $\mathrm{Br} \mathcal{F}$ Ind Med 1983;40:99-105.

25 Campara P, Andrea FD, Micciola R, Savonitto C, Tansella M, Zimmerman-Tansella C. Psychological performance of workers with blood-lead concentration below the current threshold limit value. Int Arch Occup Environ Health 1984;53:233-46.

26 Jeyaratnam J, Boey KW, Ong CN, Chia CB, Phoon WO Neuropsychological studies among workers exposed to Neuropsychological studies amon

27 Williamson AM, Teo RKC. Neurobehavioural effects of occupational exposure to lead. Br F Ind Med 1986;43. 374-80.

28 Ryan CM, Morrow L, Parkinson D, Bromet E. Low level lead exposure and neuropsychological functioning in blue collar males. Int $\mathcal{f}$ Neurosci 1987;36:29-39.

29 Ahmed NS, El-Gendy KS, El-Refaie AK, Marzouk SA Bakry NS, El-Sebae AH, Soliman SA. Assessment of lead toxicity in traffic controllers of Alexandria, Egypt. Arch Environ Health 1987;42:92-5.

30 Pasternak G, Becker CE, Lash A, Bowler R, Estrin W, Law D. Cross-sectional study of lead-exposed cohort. Clin Toxicol 1989;27:37-51.

31 Stollery BT, Banks HA, Broadbent DE, Lee WR Cognitive functioning in lead workers. $\mathrm{Br} f$ Ind $g$ Med $698-707$.

32 Mantere P, Hanninen H, Hernberg S, Luukkonen R. A prospective follow-up study on psychological effects in workers exposed to low levels of lead. Scand 7 Work Environ Health 1984;10:343-50.

33 Baker EL, Feldman RG, White RA, Harley JP, Niles CA Dinse GE, Berkey CS. Occupational lead neurotoxicity: behavioural and electrophysiological evaluation-Study design and year one results. $B r \mathcal{F}$ Ind Med 1984;41 $352-61$.

34 Baker EL, White RA, Pothier LJ, Berkey CS, Dinse GE Travers $\mathrm{PH}$, et al. Occupational lead neurotoxicity: improvement in behavioural effects after reduction of improvement in behavioural effects after

35 Yokoyama K, Araki S, Aono H. Reversibility of psychological performance in subclinical lead absorption. logical performance in subclini

36 Stollery BT, Broadbent DE, Banks HA, Lee WR. Shor term prospective study of cognitive functioning in lead workers. Br f Ind Med 1991;48:739-49.

\section{Instructions to authors}

Three copies of all submissions should be sent to: The Editor, Occupational and Environmental Medicine, BMJ Publishing Group, BMA House, Tavistock Square, London WC1H 9JR, UK. All authors should sign the covering letter as evidence of consent to publication. Papers reporting results of studies on human subjects must be accompanied by a statement that the subjects gave written, informed consent and by evidence of approval from the appropriate ethics committee. These papers should conform to the principles outlined in the Declaration of Helsinki (BMF 1964; ii:177).
If requested, authors shall produce the data on which the manuscript is based, for examination by the Editor.

Authors are asked to submit with their manuscript the names and addresses of three people who they consider would be suitable independent reviewers. They will not necessarily be approached to review the paper.

Papers should include a structured abstract of not more than 300 words, under headings of Objectives, Methods, Results, and Conclusions. Please include up to three keywords or key terms to assist with indexing. 